\title{
UPAYA MENINGKATAN PRESTASI BELAJAR MATEMATIKA MATERI \\ BANGUN RUANG SISI LENGKUNG MELALUI MODEL PEMBELAJARAN INQUIRY PADA SISWA KELAS IX DI SMP NEGERI 70 JAKARTA.
}

\author{
NURKOMARIA \\ SMP Negeri 70 Jakarta \\ nurkomaria1972@gmail.com
}

\begin{abstract}
ABSTRAK
Tujuan penelitian dengan menggunakan pendekatan pembelajaran Inquiry diharapkan peserta didik mampu meningkatkan prestasi belajar matematika terhadap materi Bangun Ruang Sisi Lengkung melalui penelitian tindakan kelas yang terdiri atas tindakan siklus I, siklus II dan siklus III. Data yang diambil dalam penelitian ini merupakan data hasil observasi, tindakan siklus I,siklus II dan siklus III serta data pendukung lainnya. Dari hasil penelitian diperoleh data telah terjadi peubahan tingkat prestasi peserta didik menjadi lebih baik. Hal ini terlihat dari perubahan hasil nilai rata-rata kelas dari 60,4 pada siklus 1 hampir sama yaitu 63,1 dengan ketuntasan 14,3\% pada siklus II rata -rata hasil belajar menjadi 72,7 dengan ketuntasan $62,5 \%$ sedangkan pada siklus III jumlah ketuntasan naik menjadi 87,5\% dengan rata-rata hasil belajar 83,4 . Dengan demikian dapat dikemukakan bahwa pembelajaran dengan menggunakan pendekatan pembelajaran Inquiry mampu meningkatkan prestasi belajar peserta didik terhadap materi Bangun Ruang Sisi Lengkung pada mata pelajaran Matematika di kelas IX SMP N . 70 semester genap tahun pelajaran 2019-2020
\end{abstract}

Kata Kunci: Prestasi belajar , Pembelajaran Inquiry, Bangun Ruang Sisi Lengkung

\section{PENDAHULUAN}

Pada pembelajaran di sekolah, guru dihadapkan pada sejumlah karakteristik siswa yang beragam. Ada siswa yang menempuh pembelajaran dengan lancar dan berhasil namun tidak sedikit pula yang mengalami kesulitan pada proses pembelajaran. Kesulitan belajar siswa ditunjukkan oleh adanya hambatan pada perkembangan maupun kesulitan belajar akademik seperti ksesulitan dalam menyelesaikan soal-soal.

Menurut Hilgard dan Brower yang dikutip oleh Hamalik 2010: 45) mendefinisikan “ Belajar adalah perubahan dan perbuatan melalui aktivitas, praktek dan pengalaman "dan berpendapat pada dasarnya pengertian belajar dapat dikembalikan dalam dua jenis pandangan,yakni pandangan modern dan pandangan tradisional.Menurut pandangan modern, belajar adalah suatu proses interkasi individu enggan lingkungannya yang dapat membawa perubahan tingkah laku pada individu yang belajar, perubahan yang terjadi merupakan hasil pengalaman dan latihan yang dialami

Inkuiri adalah salah satu strategi pembelajaran yang dikembangkan dalam dunia pendidikan. Melalui strategi ini, anak akan mengembangkan kreatifitas diri sendiri dengan bantuan yang diberikan oleh guru. Pengembangan kreatifitas anak dipentingkan dalam proses pendidikan mengingat anak secara potensial mempunyai kemampuan untuk berkreatifitas. Kreatifitas itu sendiri adalah modal dalam pencerdasan dan pendewasaaan anak. Melalui pendidikan proses pencerdasan, pendewasaan sosial dan emosional termasuk pendewasaan religius dibangun secara terarah. Pembelajaran inkuiri berarti suatu rangkaian kegiatan belajar yang melibatkan secara maksimal seluruh kemampuan siswa untuk mencari dan menyelidiki secara sistematis, kritis, logis, analitis, sehingga mereka dapat merumuskan sendiri penemuannya dengan penuh percaya diri (Gulo, 2008).

Shih, dkk. (2010) mengatakan "Inquiry Based Learning is a concept which encourages teachers to allow earners to get in touch with authentic situations, and to explore and to solve problems that are analogs to real life" yang artinya pembelajaran inkuiri adalah suatu konsep yang mendorong guru untuk memberikan kesempatan pebelajar untuk 
memperoleh ketrampilan dengan menyajikan situasi nyata, dan untuk menyelidiki dan menyelesaikan masalah yang berkaitan dengan kehidupan nyata.

Metode Inquiry adalah metode pembelajaran yang melibatkan siswa aktif dalam proses pembelajaran. Berbagai metode dapat digunakan oleh guru, namun metode yang dipilih oleh peneliti adalah metode Inquiry karena memiliki keunggulan seperti : lebih kreatif, melatih pemahaman, memecahkan masalah, interaksi, melatih keterampilan, inovatif, dan produktif,sehingga dapat meningkatkan prestasi belajarnya. Langkah-langkah model pembelajaran inkuiri menurut Sanjaya (Djuanda, 2009), Yaitu orientasi, merumuskan masalah, merumuskan hipotesis, menguji hipotesis, mengumpulkan data, dan merumuskan kesimpulan.

Mata pelajaran matematika dianggap sebagian besar siswa merupakan mata pelajaran yang sulit di mana kebanyakan kontennya bersifat abstrak. Karena hal tersebut matematika menjadi mata pelajaran yang umumnya kurang diminati siswa. Hal ini bisa menyebabkan prestasi belajar matematika menjadi rendah.

Matematika adalah salah satu mata pelajaran dasar pada jenjang pendidikan formal yang memegang peran penting. Matematika juga merupakan bidang studi yang harus bisa dikuasai oleh siswa, karena merupakan sarana pemecahan masalah sehari-hari. Namun, menurut Suyatno (2009:2) banyak siswa berpikir bahwa matematika merupakan bidang studi yang paling sulit dan jarang diminati. Pandangan siswa ini merupakan bentuk respon negatif yang mungkin dikarenakan kurangnya aspek penunjang dalam pembelajaran matematika seperti penyediaan media, bentuk pembelajaran yang membosankan, sehingga siswa tidak tertarik untuk belajar matematika. Kenyataan kurangnya aspek penunjang dalam pembelajaran matematika mengakibatkan rendahnya penguasaan matematika siswa. Hal ini sering terjadi di hampir sebagian besar pokok bahasan matematika, yang salah satunya adalah pokok bahasan bangun ruang.

Rusfendi dikutip Suriasumantri (2005: 189) mengemukakan bahwa matematika adalah ilmu pengetahuan yang padat dan tidak mendua, lebih lanjut disebutkan bahwa tujuan pengajaran matematika adalah untuk meluruskan dan melatih siswa untuk menemukan kebenaran yang hakiki dengan berpedoman pada koonsisten kebenaran yang dikembangkan melalui konsep dan dalil yang ada Ohlson dikutip Jujun S Suriasumantri (2005: 1890) menyampaikan bahwa dengan memahami konsep dan prinsip matematika menjadi lebih mudah.

Pembelajaran matematika adalah suatu proses atau kegiatan guru mata pelajaran matematika dalam mengajarkan matematika kepada para peserta didiknya, yang di dalamnya terkandung upaya guru untuk menciptakan iklim dan pelayanan terhadap kemapuan , potensi, minat, bakat dan kebutuhan peserta didik tentang matematika yang aat beragam agar terjadi interaksi optimal antara guru dan peserta didik serta antara peserta didik dengan peserta didik dalam mempelajari matematika tersebut (Suyitno,2004:2)

Pada kenyataannya, prestasi belajar matematika siswa masih tergolong rendah. Hal ini dapat ditunjukkan dengan rendahnya nilai ulangan harian siswa yang masih dibawah KKM. Menurut data dari Trends in Mathematics and Science Study (TIMSS), prestasi belajar matematika Indonesia berada pada urutan ke-38 dari 42 dengan skor rata-rata 386. (Mullis, 2012: 42). Dari data tersebut menunjukkan ratarata hasil belajar matematika masih tergolong rendah.

Reid sebagai seorang orthopedagogist di bidang kesulitan belajar dalam Jamaris Martini (2014) juga mengemukakan bahwa kesulitan yang dialami oleh anak adalah sebagai berikut: a) Kelemahan dalam menghitung, b) Kesulitan dalam mentransfer pengetahuan, c) Pemahaman bahasa matematika yang kurang, d) Kesulitan dalam presepsi visual

Prestasi belajar dikatakan berhasil apabila siswa secara individual telah memperolah nilai nilai $\geq$ KKM, dan secara klasikal dikatakan tuntas belajar jika lebih dari $85 \%$ siswa mendapat nilai $\geq$ KKM. Di samping itu dilakukan juga metode analisis deskriptif yang merupakan pemaparan dari hasil penerapan pembelajaran dengan media benda asli. 
Dalam materi Bangun Ruang Sisi Lengkung pada mata pelajaran Matematika, sebagian sekolah masih menerapkan pembelajaran konvensional yang menyebabkan materi belajar matematika tidak tersampaikan dengan baik kepada peserta didik. Di SMP Negeri 70 , pembelajaran model ini masih berlangsung dan peneliti mendapatkan hasil rata-rata pembelajaran di kelas IX dengan KKM untuk mata pelajaran Matematika sebesar 73 sebagai berikut:

Tabel 1. Hasil belajar peserta didik pada tiap kelas pada materi Bangun Ruang Sisi Lengkung

\begin{tabular}{|l|c|c|c|c|c|c|}
\hline Kelas & IX-A & IX-B & IX-C & IX-D & IX-E & IX-F \\
\hline Rata-rata & 65,3 & 60,4 & 72,4 & 78,6 & 75,9 & 73,4 \\
\hline
\end{tabular}

Data di atas menunjukkan adanya satu kelas yang paling rendah nilai rata-ratanya, yakni kelas IX-B dengan nilai rata- rata 60,4. Atas dasar itu akhirnya peneliti memilih kelas IX-B sebagai objek penelitian. Untuk memperkuat data rendahnya nilai rata-rata materi Bangun Ruang Sisi Lengkung di kelas IX -B,dengan melihat data nilai pada peserta didik di kelas tersebut dengan ketuntasan masih jauh di bawah 85\% dengan KKM sebesar 73.

Atas dasar pertimbangan tersebut peneliti akhirnya memilih kelas IX-B sebagai obyek penelitian. Hal ini didasarkan pada pengamatan awal dimana kelas IX-B memiliki kemampuan prestasi belajar paling rendah diantara kelas-kelas yang lain dan juga data awal yang menunjukkan permasalahan yang ada di kelas tersebut. Permasalahan prestasi belajar yang ada di kelas tersebut perlu dilakukan tindakan agar peserta mampu mencapai kemampuan yang lebih baik.

Dalam pandangan peneliti, pembelajaran matematika di SMP N.70 Jakarta masih berpusat pada guru,yaitu masih bersifat konvensional, guru lebih mendominasi pembelajaran dengan metode ceramah dan peserta didik kurang kreatif sehingga peserta didik menjadi pasif dan mengabaikan kemampuan intelektual lain yang lebih tinggi tingkatannya.

Dalam pengamatan awal peneliti, peneliti menemukan permasalahan dalam pembelajaran matematika terutama di kelas IX-B . Hasil prestasi belajar pada materi bangun ruang sisi lengkung yang rendah dikarenakan pendekatan pembelajaran matematika yang masih bersifat konvensioanal dengan tidak menggunakan startegi pembelajaran yang berpusat pada peserta didik.

Rendahnya prestasi belajar pada materi bangun ruang sisi lengkung pada kelas IX-B di SMP N. 70 Jakarta adalah fakta dalam proses pembelajaran yang perlu mendapat tindakan tententu. Dalam hal ini guru dituntut mampu mengatasinya dengan memilih pendekatan yang tepat untuk peserta didik yaitu dengan pembelajaran Inquiry. Pembelajaran Inquiry. merupakan salah satu upaya yang tepat yang perlu dipraktekkan dalam proses pembelajaran karena rangkaian kegiatan pembelajaran yang menekankan pada proses berpikir secara kritis dan analisis untuk mencari dan menemukan sendiri jawaban dari suatu masalah yang dipertanyakan pada proses itu sendiri, biasanya dilakukan melalui tanya jawab antara guru dan peserta didik.

Dari hasil wawancara dan pengamatan ada beberapa factor yang kemungkinan berasal dari dalam diri peserta didik.Kesulitan memamahi konsep bangun ruang sisi lengkung menyebabkan peserta didik mengalami kesulitan dalam menyelesaikan soal. Hasil wawancara peneliti kepada peserta didik menunjukkan beberapa penyebab kesulitan yang dialami peserta didik yaitu kebingungan peserta didik dalam menentukan tinggi kerucut dengan menggunakan teorema Pythagoras. Peserta didik umumnya hanya menguasai konsep dari teorema phytagoras jika diminta untuk menentukan sisi miringnya, pada bangun kerucut yaitu garis pelukis. Peserta didik juga mengalami kesulitan membedakan selimut kerucut dan ruas garis pelukis, karena menganggap selimut dan ruas garis pelukis merupakan hal yang sama. Biasanya kesulitan yang dialami siswa dikarenakan peserta didik lupa akan rumus mencari volume bangun ruang sisi lengkung yaitu tabung, kerucut, dan bola. 
Pemahaman konsep yang dimaksud adalah paham akan sifat bangun ruang sisi lengkung, komposisi dari bangun ruang tersebut, serta paham akan langkah-langkah dalam penemuan rumus untuk menentukan volume dan luas permukaan bangun ruang sisi lengkung, dan salah satunya adalah dengan dapat melaksanakan pembelajaran inquiry dengan pendekatan saintific

Berdasarkan pada kondisi nyata di SMP N. 70 Jakarta, khususnya kelas IX-B peneliti bermaksud mengadakan penelitian tindakan kelas untuk memecahkan permasalahan rendahnya Prestasi belajar peserta didik dalam memahami konsep pada materi bangun ruang sisi lengkung dengan menggunakan pembelajaran inquiry dengan pendekatan saintific. Terlebih dahulu bekerjasama dengan teman kolaborator sebagai observer ke dua yaitu rekan guru pada mapel bidang yang sama dari kelas IX yang berbeda

Ruang lingkup penelitian tindakan kelas ini meliputi dua hal yakni: lingkup subjek dan lingkup formal. Dalam lingkup subjek, peneliti memilih kelas IX-B dikarena kelas tersebut memiliki prestasi belalar pada materi bangun ruangg sisi lengkung paling rendah dibanding kelas lainnya. Keadaan ini mengindikasikan bahwa kelas tersebut memiliki permasalahan yang harus segera ditemukan pemecahannya.. Adapun lingkup formal dalam penelitian ini adalah untuk mengetahui penerapan pembelajaran inquiry yang dilaksanakan serta untuk mengetahui tingkat prestasi belajar peserta didik di kelas IX-B setelah diterapkannya pembelajaran Inqury dalam mata pelajaran matematika.Karena pada Inquiry dapat diimplementasikan secara terpadu dengan strategi lain sehingga dapat membantu pengembangan pengetahuan dan pemahaman matematika serta kemampuan melakukan kegiatan Inquiry oleh siswa

Setiap peserta didik memiliki tingkat perkembangan yang berbeda-beda satu sama lain, ada peserta didik yang dapat dengan mudah menerima materi dan ada juga yang merasa kesulitan dalam menerima materi, kemungkinan hal itu disebabkan karena menurut Sudjana dikutip Dmyati (2009 : 42) menyatakan prestasi belajar adalah beragam kemampuan yang dimiliki siswa setelah ia menerima pengalaman belajar. Prestasi belajar matematika berkenaan dengan kemampuan siswa menggunakan beragam operasi matematika, seperti operasi aljabar, geometri, statistic, dan beragam materi ajar yang disampaikan kepada siswa

Penerapan pembelajaran inquiry dalam mata pelajaran matematika pada materi Bangun ruang sisi lengkung adalah kelompok bangun ruang yang memiliki bagian - bagian yang berbentuk lengkungan. Biasanya bangun ruang tersebut memiliki selimut atau ataupun permukaan bidang. Adapun yang termasuk bangun ruang sisi lengkung Bangun tiga dimensi yang, yaitu bangun yang dapat dilihat dari semua sisinya. Media pembelajaran berupa model bangun ruang dapat dijadikan media pengajaran. Dengan media visual sangat membantu guru dalam menerangkan sesuatu kepada siswa untuk memahami materi yang disampaikan.

Pembelajaran Inquiry adalah rangkaian kegiatan pembelajaran yang menekankan pada proses berpikir secara kritis dan analisis untuk mencari dan menemukan sendiri jawaban dari suatu masalah yang dipertanyakan pada proses itu sendiri, biasanya dilakukan melalui tanya jawab antara guru dan siswa. Guru bertindak sebagai fasilitator yang memfasilitasi dan membantu peserta didik untuk mengaitkan antara apa yang mereka terima di sekolah dengan kehidupan mereka sehari-hari. Dari sini nampak bahwasanya pembelajaran inquiry patut dipertimbangkan untuk digunakan dalam mengajarkan matematika kepada peserta didik.

Tujuan dari penelitian ini ialah untuk mengetahui bagaimana cara meningkatkan hasil belajar peserta didik pada materi bangun ruang sisi lengkung serta ada atau tidaknya peningkatan prestasi belajar matematika melalui pembelajaran inquiry pada materi bangun ruang sisi lengkung pada kelas IX -B di SMP N. 70 Jakarta

\section{METODE PENELITIAN}

Prosedur penelitian yang digunakan dalam penelitian ini adalah penelitian tindakan kelas. Rancangan yang digunakan adalah model rancangan yang dikembangkan oleh Stephen Kemmis dan Mc. Taggart (dalam Arikunto, 2006:97) dengan menggunakan dua siklus, masingmasing siklus terdiri dari empat tahap yakni: 1) Merencanakan (plan), 2) Melakukan Tindakan (act), 3) Mengamati (observe), 4) Refleksi (reflect). 
Berikut ini adalah gambar rancangan penelitian tindakan kelas menurut Stephen Kemmis dan Mc. Taggart.

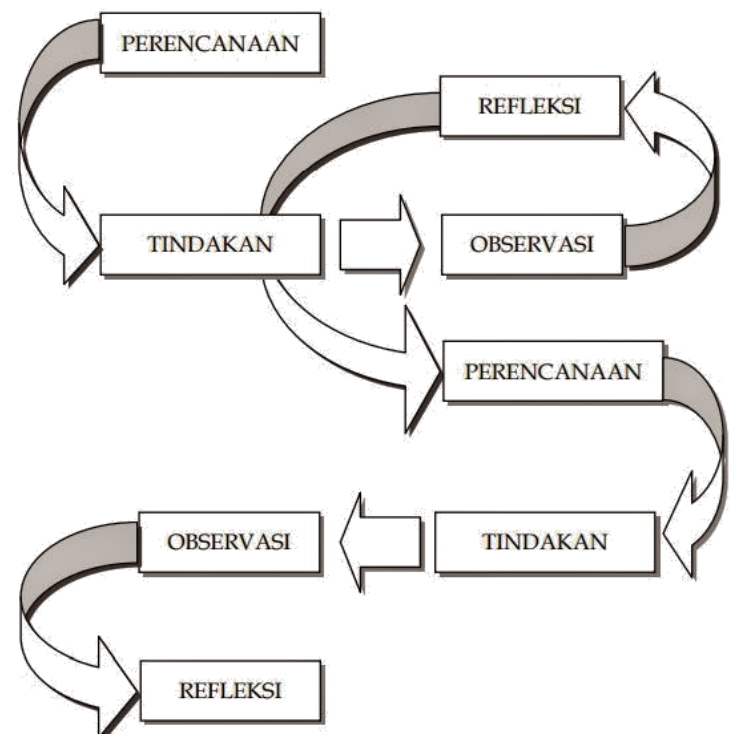

Gambar 1. Tahapan dalam siklus Penelitian Tindakan Kelas Model Kemmis \& Taggart. Sumber: Arikunto,2006:97.

Penelitian ini dilakukan dengan tindakan yang dilaksanakan dengan langkah-langkah penelitian yang telah direncanakan, yaitu dengan terlebih dahulu menyusun RPP yang berisi langkah-langkah dalam pelaksanaan pembelajaran. Langkah selanjutnya adalah berupa pengumpulan data yang dilalksanakan dengan melakukan Setelah data diperoleh kemudian dilakukan refleksi dan melakukan laporan hasil penelitian. Tindakan siklus I pertemuan pertama dilaksanakan pada hari selasa , 28 Januari 2020 dan pertemuan kedua pada kamis , 30 Februari 2020. tindakan siklus II pertemuan pertama dilaksanakan pada hari selasa 04 Februari 2020 dan pertemuan kedua pada hari kamis 04 Februari 2020, sedangkan siklus ke III , yaitu hanya pada satu pertemuan saja hari selasa 11 Februari 2020

Data yang diperoleh dari penelitian ini berupa data awal yang didapatkan dari data prestasi hasil belajar matematika pada materi bangun rruang sisi lengkung, kemudian dari data awal didapatkan informasi bahwa peserta didik memerlukan tindakan untuk memecahkan permasalahan rendahnya hasil belajar materi bangun ruang sisi lengkung dan selanjutnya peneliti melakukan penelitian dengan tiga siklus

Data inti diperoleh selama tindakan. didukung oleh guru dan teman sejawat yaitu berupa kelemahan-kelemahan serta hambatan yang ditemukan yang selanjutkan dipakai sebagai dasar perbaikan pada siklus berikutnya.

\section{HASIL DAN PEMBAHASAN}

\section{Siklus I Pertemuan Pertama}

Pelaksanaan siklus I pertemuan pertama dilaksanakan 2 x 40 menit yaitu pada hari selasa ,28 Januari 2020. Pada saat itu guru masuk ke ruang kelas IX-B bersama dengan observer pada pukul 08.10 WIB. Kegiatan pendahuluan dilakukan selama 10 menit dengan yakni dengan menyampaikan contoh benda - benda di skeliling yang berbentuk tabung. Guru membuka pelajaran dengan memberikan salam, melakukan presensi kepada peserta didik secara komunikatif, kemudian guru memberikan apersepsi berupa stimulus kepada peserta didik berupa pertanyaan seputar materi yang akan diajarkan. Setelah itu guru memotivasi peserta didik menjelaskan kepada siswa tentang pentingnya mempelajari materi ini, agar siswa dapat mengaplikasikannya dalam kehidupan sehari-hari.

Kegiatan inti berlangsung selama 65 menit dengan melakukan tahapan pembelajaran inqury yang terdiri dari beberapa fase, yaitu fase ke 1 orientasi masalah, fase ke 2 dengan merumuskan masalah, fase ke 3 mengajukan hipotesis, fase ke 4 merencanakan pemecahan 
masalah, ,fase ke 5 melakukan eksperimen, fase ke 6 ,melakukan pengamatan dan pengumpulan data, fase ke 7 analisis data dan fase ke 8 penarikan kesimpulan

Pada kegiatan penutup selama 5 menit , guru melakukan refleksi pembelajaran bersama dengan peserta didik. Kemudian menyampaikan pembelajaran untuk pertemuan selanjutnya yaitu kamis , 30 Januari 2020. Guru meminta kepada peserta didik untuk mempelajari kembali materi yang telah dipelajari yaitu unsur - unsur bangun ruang sisi lengkung dan luas bangun ruang tabung, serta materi untuk minggu berikutnya yaitu volume tabung. Setelah itu guru menutup pembelajaran dengan mengucapkan salam.

\section{Siklus I Pertemuan Kedua}

Pertemuan kedua dilangsungkan 3 x 40 menit pada hari kamis , 30 Januari 2020. Guru melakukan kegiatan pendahuluan selama kurang lebih 10 menit dengan menberi salam dan presensi dengan komunikatif. Guru kemudian memberikan apersepsi dengan mengaitkan pembelajaran pada pertemuan sebelumnya yang bertujuan untuk mengingatkan peserta didik akan pembelajaran yang telah dipelajari pada pertemuan sebelumnya.Guru menanyakan pada peserta didik tentang contoh contoh benda bangun ruang sisi lengkung yang berbentuk tabung dan rumus luas bangun runag tabung, Setelah itu guru memotivasi peserta didik menjelaskan kepada siswa tentang pentingnya mempelajari materi ini, agar siswa dapat mengaplikasikannya dalam kehidupan sehari-hari.

Kegiatan Inti ini berlangsung 80 menit, masih sama dengan melakukan tahapan pembelajaran inqury yang terdiri dari beberapa fase, yaitu fase ke 1 orientasi masalah, fase ke 2 dengan merumuskan masalah, fase ke 3 mengajukan hipotesis, fase ke 4 merencanakan pemecahan masalah, ,fase ke 5 melakukan eksperimen, fase ke 6 melakukan pengamatan dan pengumpulan data, fase ke 7 analisis data dan fase ke 8 penarikan kesimpulan dan pada 20 menit terakhir, sebelumnya berakhirnya pelajaran, diadakan evalausi secara bersama-sama tentang materi bangun ruang tabung.

Berdasarkan hasil evaluasi siklus I terjadi peningkatan dari sebelumnya yakni nilai rata rata sebelumnya yaitu 60,4 menjadi 63,1 bisa dilihat pada table distribusi berikut ini :

Tabel 2: Distribusi Hasil Evaluasi Belajar Peserta Didik Pada Siklus 1

\begin{tabular}{|c|l|c|}
\hline No & \multicolumn{1}{|c|}{ Uraian } & Siklus 1 \\
\hline 1 & Nilai rata - rata & 63,1 \\
\hline 2 & Nilai maksimum & 88 \\
\hline 3 & Nilai minimum & 45 \\
\hline 4 & Prosentase peserta didik yang tuntas & $14,3 \%$ \\
\hline 5 & Prosentase peserta didik yang tidak Tuntas & $84,37 \%$ \\
\hline
\end{tabular}

Selama siklus I ini terdapat 2 observer yaitu peneliti sekaligus pengajar dan seorang teman sejawat bertindak sebagai kolaborator atau observer. Dalam hal ini peneliti bertindak sebagai pengajar yang mempraktekkan RPP yang telah disusun bersama-sama dengan peneliti. Kegiatan pengamatan ini dilakukan dengan memberi cheklis pada lembar observasi yang telah dipersiapkan sebelumnya.

Dalam pertemuan kedua ini, peserta didik kurang memilki persiapan dalam mengikuti pembelajaran. Hal tampak ketika guru mengajukan pertanyaan, kebanyakan dari mereka masih kebingungan, sehingga guru harus memberi motivasi terlebih dahulu dan juga apersepsi mengenai gambaran awal materi yang akan diajarkan pada hari itu. Kegiatan ini berfungsi untuk membentuk kembali fokus anak setelah mendapat mata pelajaran berbeda pada jam sebelumnya.

Kekurangan yang tampak pada siklus I ini umumnya terlihat ketika peserta didik tidak mampu memahami dan menerapkan rumus luas dan volume dari materi bangun ruang tabung Tingkat hasil belajar peserta didik masih tentang unsur - unsur bangun ruang sisi lengkung . Ketidaksiapan peserta didik dalam memahami dan menerapkan rumus luas dan volume bangun 
ruang tabung tanpa harus menghafal dan menjadi kendala tersendiri karena mereka harus menunggu penjelasan dulu dari guru agar memahami materi tersebut . Kekurangan ini menyebabkan banyak waktu selama pembelajaran menjadi terbuang. Untuk mengatasi kelemahan ini guru membentuk kelompok diskusi yang dimaksudkan agar peserta didik lebih cepat dan responsif dalam memahami luas dan volume materi bangun ruang tabung

Berdasar pada kekurangan yang diperoleh dari siklus I ini maka dilakukan analisis untuk menemukan pemecahan yang tepat yang akan diterapkan pada siklus II. Pada siklus berikutnya, diharapkan adanya perbaikan-perbaikan untuk memperoleh hasil pembelajaran lebih baik. Dalam hal ini, guru kembali mengingatkan kepada peserta didik untuk lebih mempersiapkan diri terutama dalam mengerjakan soal luas dan volume bangun ruang tabung.

\section{Penelitian Siklus II}

Siklus ini dilaksanakan pada tanggal 04 Februari 2020. Pada siklus ini, kegiatan pembelajaran dilaksanakan untuk menindaklanjuti kekurangan-kekurangan yang ditemukan sebelumnya yaitu pada siklus 1 . Persiapan yang dilakukan sama dengan siklus 1 namun ada sedikit variasi dari RPP yang disusun dengan materi bangun ruang kerucut .

\section{Siklus II Pertemuan I}

Siklus II ini dilaksanakan pada tanggal 04 Februari 2020. Pada pertemuan pertama siklus ini, model pelaksanaan pembelajaran mengacu pada RPP yang telah disusun bersama-sama antar peneliti dengan guru pengajar mata pelajaran Matematika

Dalam pertemuan pertaman ini, guru sebagai peneliti beserta observer memasuki ruang kelas pada pukul 08.10 WIB untuk mempersiapkan proses pembelajaran. Pembelajaran diawali dengan salam dan sapaan dari guru kepada peserta didik untuk hanya fokus mereka pada materi luas bangun ruang sisi lengkung yaitu kerucut . Setelah melakukan presensi, guru melakukan apersepsi dengan menjelaskan keterkaitan antara materi sebelumnya dengan materi yang akan dipelajari pada hari itu. Pembukaan pada pembelajaran ini memerlukan waktu sekitar 05 menit.

Kegiatan inti pada pertemuan pertama siklus 2 ini berlangsung sekitar 40 menit. Guru mengawali kegiatan dengan memberikan contoh luas bangun ruang sisi lengkung kerucut yang lebih umum dan bersentuhan langsung dengan kehidupan sehari-hari. Pembelajaran tetap melakukan pembelajaran inquiry.Dengan memberikan lembar kerja guru meminta peserta didik untuk duduk berkelompok guna mendiskusikan lembar kerja tersebut. Guru menginstruksikan agar tiap kelompok hanya mendiskusikan hanya fokus pada luas bangun ruang sisi lengkug kerucut yang ada di lembar kerja. Dari pemaparan hasil diskusi terlihat beberapa peserta didik sudah mulai aktif. Hal ini nampak dari keberanian mereka mengangkat tangan untuk mengajukan pertanyaan kepada kelompok yang sedang melaksanakan presentasi. Kegiatan ini berakhir ketika semua kelompok sudah melaksanakan presentasi di depan kelas.

Sebelum pembelajaran berakhir, guru menjelaskan kesimpulan umum atas materi pembelajaran pada pertemuan itu. Guru juga mengingatkan kepada peserta didik menyiapkan materi pada pertemuan berikutnya dan kesiapan mereka mengikuti evalaasi di akhir pembelajaran. Lalu guru menutup kegiatan pembelajaran dengan mengucapkan salam.

\section{Siklus II Pertemuan 2}

Siklus ini berlangsung pada tanggal 11 Februari 2020 dengan alokasi waktu 3 x 40 menit. Guru melaksanakan pembelajaran sesuai dengan RPP yang telah disepakati bersama antara observer . Pada kegiatan inti ini guru menyampaikan materi volume bangun ruang sisi lengkung kerucut dengan power point tentang volume bangun ruang sisi lengkung kerucut.Pembelajaran tetap dengan melaksanakan fase fase sesuai pembelajaran inquiry.Setelah pembelajaran berlangsung guru kemudian melakukan evaluasi kepada peserta didik dengan waktu sekitar 30 menit. Kegiatan evaluasi dilakukan guna mengukur pemamahan peserta didik selama kegiatan pembelajaran berlangsung.

Berdasarkan hasil evaluasi siklus II terjadi peningkatan dari sebelumnya yakni nilai ratarata pada siklus 1 yaitu 63,1 menjadi 72,7 bisa dilihat pada table distribusi berikut ini : 
Tabel 3 : Distribusi Hasil Evaluasi Belajar Peserta Didik Pada Siklus II

\begin{tabular}{|c|l|c|}
\hline No & \multicolumn{1}{|c|}{ Uraian } & Siklus II \\
\hline 1 & Nilai rata - rata & 72,7 \\
\hline 2 & Nilai maksimum & 90 \\
\hline 3 & Nilai minimum & 52 \\
\hline 4 & Prosentase peserta didik yang tuntas & $62,5 \%$ \\
\hline 5 & Prosentase peserta didik yang tidak Tuntas & $37,5 \%$ \\
\hline
\end{tabular}

Hal ini menunjukkan bahwa hasil belajar peserta didik sudah meningkat dan lebih baik dibandingkan sebelum dilaksanakan tindakan.

Pada siklus II ini, posisi peneliti sama dengan pada siklus sebelumnya. Peneliti sebagai guru pengajar dibantu oleh teman sejawat sebagai kolaborator . Kegiatan teman sejawat sebagai kolaborator dilakukan dengan menggunakan lembar pengamatan, sedangkan guru pengajar mempraktekkan RPP yang telah disusun bersama-sama.

\section{Siklus III}

Siklus ini berlangsung 1 pertemuan saja, yaitu pada tanggal 18 Februari 2020 dengan alokasi waktu 2x 40 menit. Guru melaksanakan pembelajaran sesuai dengan RPP yang telah disepakati bersama antara guru kolaborator . Pada kegiatan inti ini guru menyampaikan materi luas dan volume bangun ruang sisi lengkung bola . Guru lebih memotivasi siswa yang sebagian masih belum bersemangat dengan sebelumnya menampilkan video pembelajaran dan siswa diminta membahasnya dengan tetap melaksanakan fase -fase pada pembelajaran Inquiry .Setelah pembelajaran berlangsung guru kemudian melakukan evaluasi kepada peserta didik dengan waktu sekitar 20 menit. Kegiatan evaluasi dilakukan guna mengukur pemahaman peserta didik selama kegiatan pembelajaran berlangsung.

Berdasarkan hasil evaluasi siklus III terjadi peningkatan dari sebelumnya yakni nilai ratarata pada siklus 1 yaitu 72,7 menjadi 83,4 bisa dilihat pada table distribusi berikut ini :

Tabel 4: Distribusi Hasil Evaluasi Belajar Peserta Didik Pada Siklus III

\begin{tabular}{|c|l|c|}
\hline No & \multicolumn{1}{|c|}{ Uraian } & Siklus III \\
\hline 1 & Nilai rata - rata & 83,4 \\
\hline 2 & Nilai maksimum & 100 \\
\hline 3 & Nilai minimum & 60 \\
\hline 4 & Prosentase peserta didik yang tuntas & $87,5 \%$ \\
\hline 5 & Prosentase peserta didik yang tidak Tuntas & $12,5 \%$ \\
\hline
\end{tabular}

Hal ini menunjukkan bahwa hasil belajar peserta didik sudah meningkat dan jauh lebih baik dibandingkan sebelum dilaksanakan tindakan.

Pada siklus III ini, posisi peneliti sama dengan pada siklus sebelumnya. Peneliti sebagai peneliti dibantu oleh teman sejawat sebagai teman kolaborator . Kegiatan rekan kolaborator dilakukan dengan menggunakan lembar pengamatan, sedangkan guru pengampu dalam hal ini peneliti mempraktekkan RPP yang telah disusun bersama-sama.

Dari hasil penelitian, ditemukan bahwa ada pengkatan hasil pembelajaran dari siklus 1 ,siklus II hingga siklus ke III. Peningkatan itu tampak terlihat dari aktifitas yang dilakukan peserta didik, begitu pula aktifitas yang dilakukan guru. Dari kedua guru baik sebagai pengamat maupun sebagai pengajar data menunjukkan bahwa kenaikan ketiga sikus terjadi cukup signifikan 

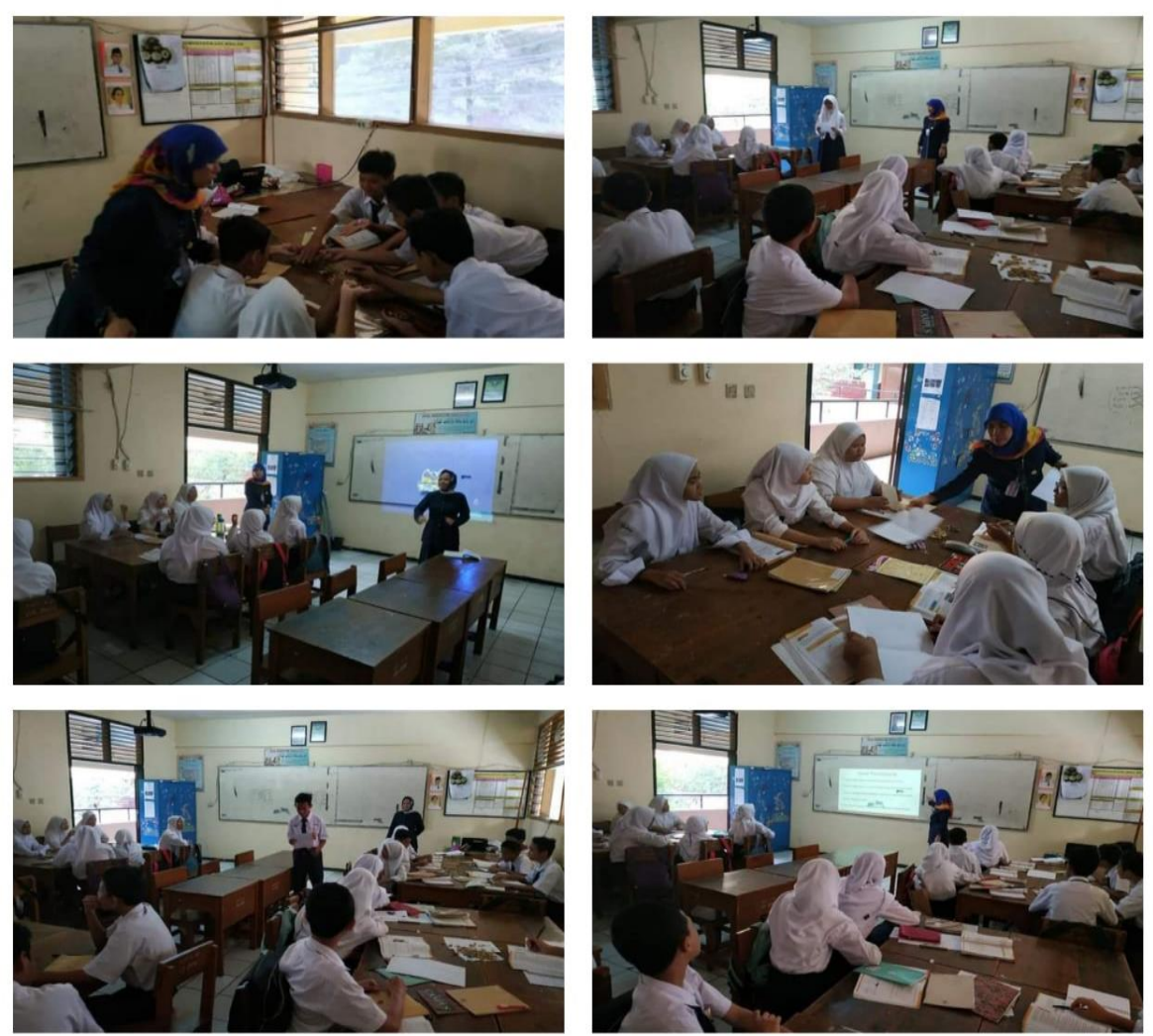

Gambar 2: Kegiatan Pembelajaran Inquiry

Perbandingan hasil evaluasi belajar peserta didik pada setiap siklus dapat di lihat dari table distibusi berikut ini :

Tabel 5 : Distribusi Hasil Evaluasi Belajar Peserta Didik pada semua siklus

\begin{tabular}{|c|l|c|c|c|}
\hline No & \multicolumn{1}{|c|}{ Uraian } & Siklus 1 & Siklus II & Siklus III \\
\hline 1 & Nilai rata - rata & 63,1 & 72,7 & 83,4 \\
\hline 2 & Prosentase peserta didik yang tuntas & $14,3 \%$ & $62,5 \%$ & $87,5 \%$ \\
\hline 3 & Prosentase peserta didik yang tidak Tuntas & $84,37 \%$ & $37,5 \%$ & $12,5 \%$ \\
\hline
\end{tabular}

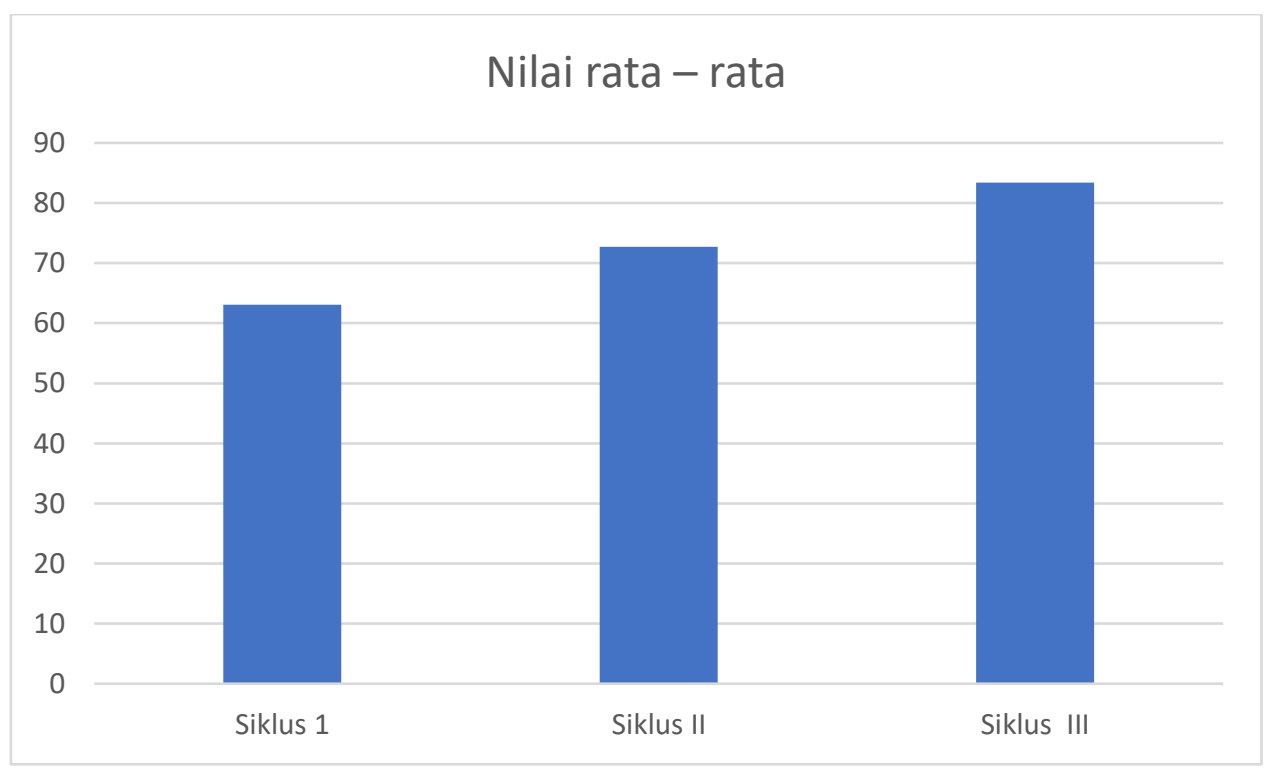

Gambar 3 : Peningkatan dari Nilai Rata - rata Hasil Evaluasi Belajar Matematika pada Materi Bangun Ruang Sisi Lengkung pada 3 Siklus 
Data diatas menunjukkan terjadi peningkatan yang cukup signifikan dari ketiga siklus tersebut. Dari sebelum tindakan rata -rata nilai 60,4 ada peningkatan di siklus 1 rata- rata nilai menjadi 63,1 . Pada siklus II menunjukkan ada peningkatan dengan kategori cukup baik dari rata- rata nilai 63,1 menjadi 72,7 dan pada siklus III dan pada akhirnya menunjukkan adanya peningkatan yang sangat baik.dari rata -rata nilai 72,7 menjadi 83,4

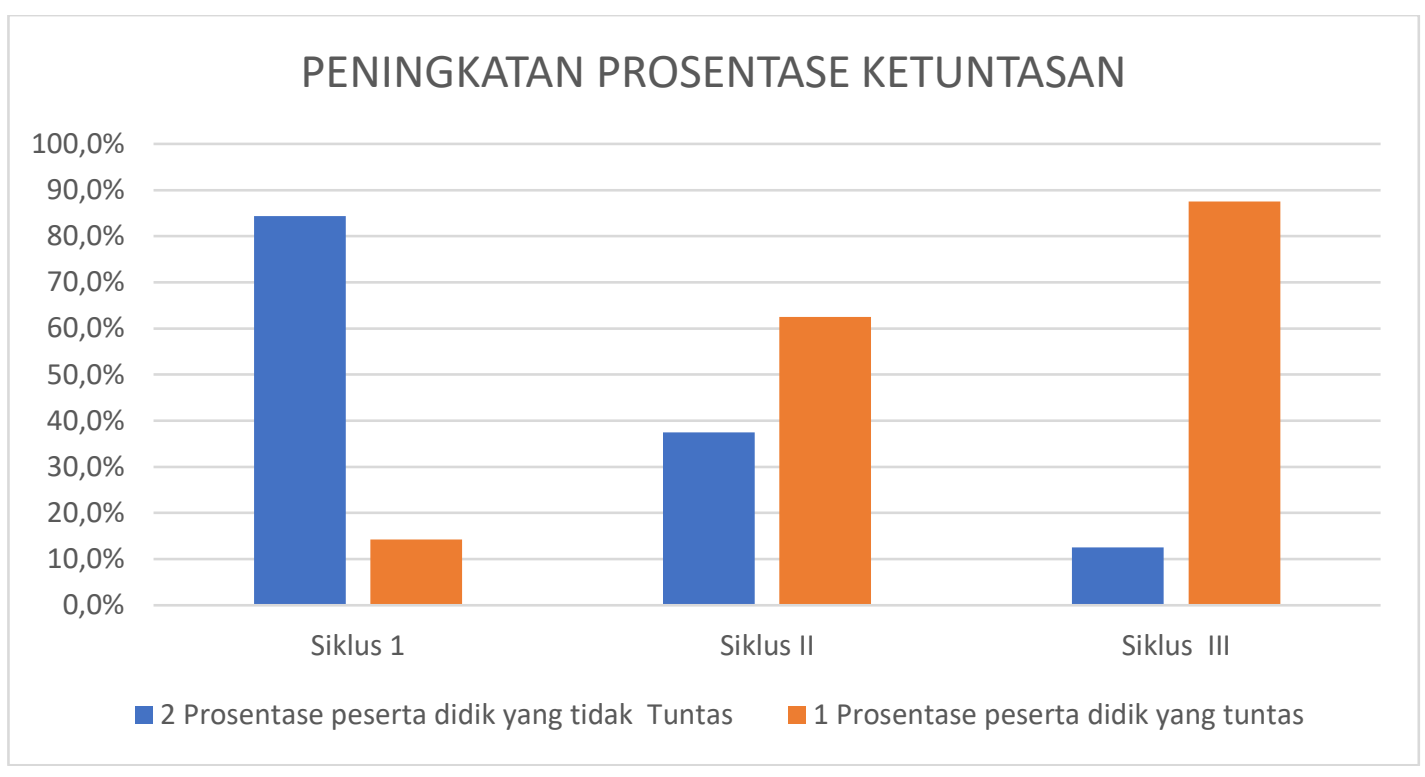

Gambar 4 : Peningkatan Prosentase Ketuntasan Hasil Evaluasi Belajar Matematika pada Materi Bangun Ruang Sisi Lengkung pada 3 siklus

Dari Grafik di atas menunjukkan bahwa ketiga siklus telah mendapati peningkatan yang sangat bagus dari rata - rata hasil belajar siswa dengan tingkat ketuntasan belajar dari siklus 1 yaitu 5 siswa atau $14,3 \%$, dan pada siklus II yang semula 5 siswa atau $14,3 \%$ menjadi 20 siswa atau 62,5\%,namun pada siklus III ketuntasan belajar peserta didik menjadi 28 siswa atau $87,5 \%$,sehingga dapat dikatakan bahwa kegiatan siswa selama pembelajaran inquiry mampu menunjukan peningkatan yang baik sekali.

Peningkatan ini karena guru dalam tahap perencanaan dan tahap pelaksanaan melakukan perbaikan-perbaikan berdasarkan temuan-temuan yang diperoleh dari siklus I. Sebagaimana yang dikemukakan oleh Sanjaya (2006), bahwa guru dalam melaksanakan aktivitas mengajar bukanlah didasarkan kepada pertimbangan-pertimbangan subjektif, tetapi didasarkan kepada suatu pertimbangan berdasarkan keilmuan yang nantinya bisa digunakan untuk memperbaiki kesalahan. Seorang guru di sekolah bukan hanya sekedar berperan sebagai penyampai materi pelajaran (transfer of knowledge), namun juga harus mampu memerankan dirinya sebagai petugas sosial, pelajar dan ilmuwan, orang tua, pencari teladan, dan pencari keamanan (Usman, 2002).

Perubahan peningkatan kemampuan peserta didik melalui pembelajaran inqury ini dipengaruhi oleh adanya kemudahan dalam penyampaian materi yang harus dikuasai peserta didik. Dengan memberi materi ringan pada awalnya dan diikuti dengan tingkat kesulitan yang lebih tinggi yaitu ,diberi tayangan power point,video pembelajaran,diskusi kelompok dengan mengikuti fase fase pada pembelajaran inqury.

Inti dari pembelajaran inquiry adalah bahwa di sini guru sebagai sumber belajar bukanlah satu satunya, masih banyak lagi sumber belajar yang dapat menunjang keberhasilan Pembelajaran,guru hanyalah sebagai fasilitator, pembimbing yang selalu mengarhakn peserta didik dalam pembelajaran. Peserta didik di sini sebagai penemu atau mencari pengetahuan dan 
menjadi bermakna itulah penetahuan dan menjadi bermakna itulah pengetahuan akan masuk ke dalam long time memories, sehingga akan selalu terkenang oleh peserta didik.Maka diharapkan guru dapat mengikuti prosedur yang ada pada pembelajaran inquiry

Dalam pembelajaran yang menggunakan model inkuiri, model pengajarannya lebih menekankan pada proses pengolahan informasi di mana peserta didik secara aktif mencari dan mengolah sendiri informasi yang kadar proses mentalnya lebih tinggi. Artinya, aktivitas pembelajaran dikendalikan oleh peserta didik (berpusat pada siswa/student's centered) melalui keterlibatannya secara aktif dalam membangun pengetahuannya sendiri. Pembelajaran yang berpusat pada siswa ini, memberikan pengalaman belajar yang nyata serta bermakna bagi siswa. Untuk siswa yang minat belajarnya rendah, hal ini tentu tidak bisa dilaksanakan. Pembelajaran yang mengakomodasi peserta didik dalam mengembangkan kemampuan berpikirnya, akan menjadi hambatan bagi peserta didik yang minat belajarnya rendah. Dengan minat yang rendah seperti kurangnya perhatian, keinginan belajar serta ketekunan berdampak pada kurang fokusnya siswa pada pembelajaran serta tidak ada dorongan untuk beraktivitas. Disamping minat siswa yang rendah, berdasarkan pengamatan kemampuan kognitifnya juga cenderung kurang, apalagi pada materi bangun ruang sisi lengkung, banyak sekali soal - soal yang perlu diselesaikan secara teliti.

Hal lain yang perlu menjadi perhatian adalah peserta didik itu sendiri. Dari pengamatan yang sudah baik itu masih didapati peserta didik yang tampak kurang fokus selama pembelajaran berlangsung. Masih terdapat beberapa dari mereka yang santai bahkan tampak ngobrol dengan temannya. Keadaan itu nampak sekali ketika waktu diskusi yang menjadi bagian penting selama kegiatan pembelajaran. Hal seperti ini tentunya membutuhkan perhatian ekstra dalam memanage kelas bagi guru. Hal ini menjadi kelemahan yang harus segera disikapi dalam pembelajaran inqury.

Keberhasilan pembelajaran salah satunya dapat dilihat dari sejauh mana siswa memahami materi yang diajarkan.Menurut (Bundu,2006), hasil belajar yakni suatu hasil yang diperoleh dari penguasaan konsep yang telah dicapai oleh siswa selama kegiatan belajar mengajar

Dari hasil nilai rata-rata yang diperoleh peserta didik dapat dirumuskan prosentase ketuntasan belajar sebagi berikut peningkatan ketuntasan belajar dari siklus I prosentase sebesar 14,3 \% meningkat pada siklus III menjadi 87,50 \% .Dan sesuai dengan apa yang telah ditetapkan pada kurikulum satuan pendidikan SMP N. 70 Jakarta bahwa ketuntasan belajar setiap kelas harus mencapai minimal $85 \%$

Pencapaian tersebut terjadi pada siklus III, hal tersebut membuktikan bahwa adanya peningkatan kinerja guru, dari setiap siklusnya terlihat bahwa ada usaha guru dalam memperbaiki perencanaan maupun pelaksanaan pembelajaran dalam menerapkan model pembelajaran inkuiri karena keberhasilan mengimplementasikan suatu model sangat bergantung kepada kepiawaian guru dalam menggunakan model tersebut. Hal ini membuktikan teori yang dikemukakan Sanjaya (2006), bahwa kepiawaian guru dalam mengimplementasikan suatu metode, strategi, atau model berpengaruh terhadap keberhasilannya.

\section{PENUTUP}

Sesuai hasil pembahasan, maka dapat dikemukakan bahwa setelah dilakukan tindakan dengan menggunakan pembelajaran inquiry pada peserta didik kelas IX - B di SMP N. 70 Jakarta semester genap Tahun pelajaran 2019-2020 terjadi perubahan kemampuan siswa dalam rata - rata nilai prestasi belajar dalam materi bangun ruang sisi lengkung pada mata pelajaran matematika. Perubahan ini nampak pada hasil observasi maupun pos test yang didapat dari pre tindakan, tindakan pada siklus I,siklus II dan tindakan dari siklus III.

Data perkembangan hasil peningkatan prestasi peserta didik terhadap materi bangun ruang sisi lengkung didapatkan dari hasil rata-rata awal sebesar 52,4, evaluasi siklus I sebesar 63,1 dan evaluasi pada siklus II dengan hasil 72,7 namun masih dilanjutkan dengan satu pertemuan pada siklus III dengan hasil rata - rata nilai menjadi 83,4.Peningkatan hasil ini 
sejalan dengan peningkatan prosentase ketuntutasan belajar, yakni dari 32 siswa dari ketuntasan pada siklus I cuma 5 siswa atau 14,3\% ,setelah dilaksanakan siklus III berubah menjadi 28 anak atau 87,5\% ,sehingga sesuai dengan yang diharapkan, yaitu mampu memperoleh nilai ketuntasan diatas KKM , dengan ketuntasan belajar dikelas minimal mencapai $85 \%$.

Dengan hasil penelitian ini, disarankan kepada kepala sekolah untuk menggunakannya sebagai dasar pembinaan agar guru menggunakan metode yang lebih bervariasi dan dasar penilaian kinerja guru dalam kompetensi profesional. Sedangkan guru diharapkan mampu menerapkan pembelajaran kontekstual untuk meningkatkan pemahaman peserta dalam mata pelajaran yang diampu.

\section{DAFTAR PUSTAKA}

Hamalik,Oemar. (2010). Psikologi Belajar Mengajar,Bandung : Sinar Baru Algensindo W. Gulo. (2008). Strategi Belajar-Mengajar. Jakarta. Grasindo.

Ju-ling Shih, dkk. (2010). An Inquiry-based Mobile Learning Approach to Enhancing Social

Science Learning Effectiveness.Jurnal of Educational Technology\&Society.13(4),50-62 Djuanda, dkk. (2009). Model pembelajaran di sekolah dasar. Sumedang: UPI Sumedang Press.

Suyatno. (2009). Menjelajah Pembelajaran Inovatif. Sidoarjo: Masmedia Buana Pustaka Suriasumantri,Jujun.S. (2009). Filsafat Ilmu Sebuah Pengantar Populer, Jakarta: Sinar Harapan

Suyitno, A. (2004). Dasar dan Proses Pembelajaran Matematika I, Semarang : Universitas Negeri Semarang

Mullis, I.V.S., Martin, M.O., Foy, P., Arora, A. (2012). TIMSS 2011 Internasional Results in Mathematics. United States: IEA.

Jamaris, M. (2014) . Kesulitan belajar. Bogor, Indoensia: Ghalia Indonesia.

Usman, M. U. (2002). Menjadi Guru Profesional. Bandung: PT. Remaja Rosdakarya.

Dimyati. (2009). Belajar dan Pembelajaran, Jakarta, Rineka Cipta.

Arikunto, Suharsimi. (2007). Manajemen Penelitian Jakarta :Rineka Cipta

Sanjaya, W. (2006). Strategi pembelajaran. Jakarta: Kencana Prenadamedia

Group.Kementrian

Usman, M. U. (2002). Menjadi Guru Profesional. Bandung: PT. Remaja Rosdakarya.

Pendidikan Dan Kebudayaan. (2018). Buku Paket Matematika kelas 9 (IX) Kurikulum 2013 edisi revisi 2018

Bundu, P. (2006). Penilaian Ketrampilan proses dan Sikap Ilmiah, Jakarta : Departemen Pendidikan Nasional Direktorat Jendral Pendidikan Tingkat Tinggi Direktorat Ketenagaan 